\title{
Ustawa budżetowa na 2016 rok - problematyka prawna
}

\author{
The Polish Budget Act for 2016: Legal Issues
}

Streszczenie. Ustawa budżetowa na 2016 r. ustala roczne dochody, wydatki, przychody, rozchody, koszty, wynagrodzenia, stawki należności, odpisy na fundusze. Ustalenia te dotyczą gospodarki finansowej rządu i innych części gospodarki finansowej państwa. Ustawa budżetowa zawiera postanowienia wynikające z wielu ustaw. Jest rozwinięciem lub wykonaniem uregulowań ujętych w całym ustawodawstwie. Ustawa budżetowa na 2016 r. zawiera trzy wymagane przez ustawę o finansach publicznych części: budżet, załączniki, inne postanowienia. Głównym elementem ustawy budżetowej jest budżet państwa (budżet ogólny), a innymi składnikami tej ustawy są budżety (plany finansowe) uzupełniające. Dla budżetu i planów finansowych (ujętych w ustawie budżetowej) należy stosować adekwatne do ich natury nazwy ich operacji finansowych: dochody i wydatki (dla budżetu państwa), przychody i koszty (dla budżetów uzupełniających), przychody i rozchody (dla planu finansowania potrzeb pożyczkowych). Zależy to m.in. od kasowej lub memoriałowej metody ujmowania zdarzeń finansowych.

Słowa kluczowe: struktura ustawy budżetowej; budżet państwa i budżety uzupełniające; ustawa budżetowa a inne ustawy. 


\begin{abstract}
The article presents the legal content and system of the 2016 Budget Act and the legal significance of its regulations. The Budget Act for 2016 contains three parts: the state budget (general budget), complementary budgets, other legal provisions. The state revenues, expenditure, expenses, salaries, rates of some state levies are determined in the Budget Act. The regulations of the Budget Act relate to the financial activity of government and other parts of the state. The complex Budget Act contains provisions resulting from the many legal acts.
\end{abstract}

Keywords: the structure of the Budget Act; the state budget and complementary budgets; the Budget Act and other legal acts.

\title{
1. Przedmiot i cel opracowania
}

Ustawa budżetowa na rok 2016 z dnia 25 lutego 2016 r. ${ }^{1}$ ustala w sposób prawnie wiążący odpowiednie kwoty i wielkości dochodów, wydatków, deficytów budżetowych, przychodów i rozchodów budżetowych, poszczególnych rodzajów dotacji, wynagrodzeń w sferze budżetowej, funduszów celowych, przychodów i kosztów niektórych podmiotów państwowych, stawek należności państwowych, innych elementów gospodarki budżetowej państwa na rok 2016. Ustawa ma 40 artykułów, w większości mających treść bardzo ogólną, zawierających odesłanie do załączników. Większość ustaleń budżetowych ujęta jest w załącznikach do ustawy, których jest 19. Ustawa łącznie z załącznikami jest obszernym aktem prawnym liczącym kilkaset stron.

Celem opracowania jest przedstawienie treści prawnej ustawy budżetowej na 2016 r., znaczenia i charakteru jej postanowień, struktury i układu tej ustawy. Ustawę budżetową na 2016 rok należy oceniać w aspekcie wymogów prawnych. Wymogi te zawarte są w Konstytucji RP, w ustawie o finansach publicznych i innych ustawach. Regulacje ustawy budżetowej i ich zakres wywołują różne pytania, oceny, uwagi de lege ferenda. Treść ustawy budżetowej w dominującym stopniu określają przepisy ustawy z 27 sierpnia 2009 r. o finansach publicznych ${ }^{2}$.

Dz.U. z 2016 r. poz. 278.

Tekst jedn. Dz.U. z 2013 r., poz. 885 ze zm., dalej: u.f.p. 
Ustawa weszła w życie z dniem ogłoszenia (tj. z dniem 4 marca 2016 r.) z mocą od dnia 1 stycznia 2016 r. Do dnia jej ogłoszenia występowała sytuacja, w której nie istniał budżet jako ustawa przyjęta przez parlament. Zgodnie z art. 219 ust. 4 Konstytucji RP z 1997 r. ${ }^{3}$ gospodarka finansowa państwa prowadzona jest wtedy na podstawie projektu ustawy budżetowej. Od 1 stycznia 2016 r. do 4 marca 2016 r. istotne znaczenie miał więc rządowy projekt budżetu. W wielu konstytucjach - dla przypadków nieuchwalenia budżetu przed rozpoczęciem roku - wprowadzana jest instytucja prorogacji budżetowej (tj. swoistego przedłużenia budżetu poprzedniego roku budżetowego na następny rok).

Ustalenia ustawy budżetowej są regulacjami prawnymi, pełnią funkcje prawne. W szczególny sposób dotyczy to ustaleń w zakresie wydatków budżetowych, które związane są z określonymi sankcjami za ich naruszenie. Taki charakter tych ustaleń ma służyć temu, aby utrzymać poziom i strukturę rocznych wydatków w wyznaczonym ustawą budżetową kształcie. Przekroczenie ustaleń wydatkowych przez wykonawców budżetowych jest naruszeniem ustawy o finansach publicznych, ustawy budżetowej, innych ustaw. Zasadniczo jest czynem będącym naruszeniem dyscypliny finansów publicznych określonym w ustawie z 17 grudnia 2004 r. o odpowiedzialności na naruszenie dyscypliny finansów publicznych $^{4}$, zwłaszcza art. 11 tej ustawy.

Podkreślić jednak trzeba, że niezależnie od rodzajów i charakteru sankcji za naruszenie różnego typu uregulowań ustawy budżetowej, ustawa ta obowiązuje jako całość, jest aktem, który muszą stosować wszystkie podmioty prawa (ogół adresatów regulacji prawnych).

Art. 109 ust. 2 u.f.p. stanowi, że ustawa budżetowa składa się z:

1. budżetu państwa (ustaleń bezpośrednio określających dochody i wydatki oraz przychody i rozchody budżetu państwa),

2. załączników (które dotyczą m.in. państwowej gospodarki finansowej nieobjętej budżetem, np. planów finansowych funduszy celowych, planów finansowych niektórych państwowych osób prawnych),

\footnotetext{
Dz.U. Nr 78, poz. 483 ze zm.

Dz.U. z 2013 r. poz. 168, ze zm.
} 
3. postanowień, których obowiązek zamieszczenia w ustawie budżetowej wynika z ustawy o finansach publicznych i z odrębnych ustaw (np. postanowień o wynagrodzeniach w służbie cywilnej, odpisach na fundusze ubezpieczeń społecznych, etatach Policji, kwotach bazowych, stawkach należności).

Ustawa budżetowa na 2016 r. zawiera wszystkie te trzy elementy (budżet, załączniki, inne postanowienia). Zauważyć także trzeba, że układ i treść ustawy budżetowej na 2016 rok są w zasadzie analogiczne do układu i treści ustawy budżetowej na 2015 r. ${ }^{5}$

\section{Treść i struktura ustawy budżetowej \\ na 2016 r. (budżetu państwa, załączników, innych postanowień)}

\section{a) budżet państwa}

Na obraz prawny ustawy budżetowej na 2016 r. składają się regulacje zawarte w 40 artykułach i w 19 załącznikach, które są rozwinięciem tego, o czym stanowi dany artykuł ustawy. Dochody ustalone w załącznikach ujęte są w podziale na jednostki klasyfikacji budżetowej (części, działy budżetowe). Załącznik nr 1 ustala kwotę dochodów budżetu państwa. Natomiast wydatki ujęte $\mathrm{w}$ załączniku $\mathrm{nr} 2$, gdzie są ustalone granice i dziedziny rocznych wydatków (innymi słowy - upoważnień do dokonywania tych wydatków). Ustalenia załączników nr 1 i 2 to główny element ustawy budżetowej. Ustalenia te tworzą konstrukcję, która można określić jako budżet centralny państwa. Jest on głównym elementem polskich finansów publicznych, powiązany jest różnymi dotacjami lub wpłatami z budżetami innych, wyodrębnionych dziedzin gospodarki finansowej państwa.

Art. 1 ust. 1 ustawy budżetowej na 2016 r. ustala łączną kwotę podatkowych i niepodatkowych dochodów budżetu państwa w wysokości

5 Por. A. Borodo, Ustawa budżetowa na 2015 rok oraz propozycje zmian układu ustawy budżetowej w Polsce, „Prawo Budżetowe Państwa i Samorządu” 2015, nr 1(3), s. 9-26. 
313,808 mld zł. Wysokość tych dochodów (z podatku od towarów i usług, podatku akcyzowego, podatków dochodowych, podatku od niektórych instytucji finansowych, podatku od gier, ceł, dywidend, wpłat z zysku, dochodów państwowych jednostek budżetowych) ustala załącznik nr 1. Dochody z podatków ustalono na 276,140 mld zł, dochody niepodatkowe na 35,930 mld, a środki z UE na 1,737 mld zł.

W art. 1 ust. 2 ustala się - zgodnie z załącznikiem nr 2 - łączną kwotę wydatków budżetu państwa w wysokości 368,548 mld zł. Ustalenia załącznika nr 2 wyrażone w podziale wydatków według części (kilkudziesięciu): działów (ponad 30) i rozdziałów budżetowych (kilkuset). Ustalenia załącznika nr 2 mają charakter prawnie wiążący, uzasadniający odpowiedzialność kierowników jednostek organizacyjnych państwa (stojących z reguły na czele rozdziału budżetowego) i innych osób za naruszenie dyscypliny finansów publicznych. W załączniku tym nie ma szczegółowego podziału wydatków na paragrafy budżetowe, jednak ustalone są wydatki w poszczególnych rozdziałach w ujęciu: dotacje i subwencje, świadczenia na rzecz osób fizycznych, wydatki bieżące jednostek budżetowych, wydatki majątkowe, wydatki na obsługę długu Skarbu Państwa, współfinansowanie projektów z udziałem środków UE.

Konsekwencją ustaleń o wysokości dochodów i wydatków jest przepis ustawy ustalający deficyt budżetu państwa na 31 grudnia 2016 r. na kwotę nie większą niż 54,740 mld zł (art. 1 ust. 5). Poziom ustalonego deficytu jest różnicą pomiędzy wskazanymi wyżej wydatkami i dochodami.

W art. 1 w ust. 3 i 4 ustalone są planowane wydatki i limity wydatków organów i jednostek, o których mówi art. 9 pkt. 1-3, pkt 8 i pkt 9 u.f.p. Chodzi tu o organy władzy publicznej, jednostki budżetowe, jednostki samorządu terytorialnego, fundusze ubezpieczeń społecznych, Narodowy Fundusz Zdrowia i inne jednostki (Fundusz Pracy, Bankowy Fundusz Gwarancyjny, fundusze przekazane Bankowi Gospodarstwa Krajowego). Zauważyć przy tym trzeba, że Bankowy Fundusz Gwarancyjny i Bank Gospodarstwa Krajowego nie są jednostkami sektora finansów publicznych. Ustalenia te (z art. 1 ust. 3 i 4) nawiązują do przepisów tzw. reguły wydatkowej, określonej w ramach wzoru przewidzianego w art. 112aa u.f.p. Ustalenia związane z obliczeniami przewidzianymi przez 
regułę wydatkową są ujmowane w ustawie budżetowej, ponieważ wymaga tego art. 110 pkt 2a u.f.p. W ustawie budżetowej ustalone są więc planowane wydatki i limity wydatków organów i jednostek włączonych w system reguły wydatkowej (określony w art. 112aa u.f.p.). Ustalone są dwie wielkości: 728,465 mld (to kwota planowanych wydatków wspomnianych organów i jednostek) oraz 553,505 mld (to kwota limitu wydatków niektórych ze wspomnianych organów i jednostek). Wielkości te, związane z przepisami art. 112aa u.f.p., są więc znacznie wyższe niż ustalona w art. 1 ust. 2 ustawy budżetowej kwota wydatków budżetu państwa.

Sens prawny ustaleń z art. 1 ust. 3 i 4 ustawy budżetowej związanych z obliczeniami przewidzianymi w regule wydatkowej budzi jednak wątpliwości. Sądzę, że ustalenia te mają znaczenie kontrolne i dyscyplinujące dla organów, które przygotowują i wykonują budżet. Jest jednak dyskusyjne, czy syntetyczne ustalenia wynikające z obliczeń zawartych w przepisach o regule wydatkowej łączą się z sankcjami za ich naruszenie? Dotyczą one m.in. podmiotów niewchodzących w skład budżetu państwa (np. dotyczą Bankowego Funduszu Gwarancyjnego, jednostek samorządu terytorialnego, Narodowego Funduszu Zdrowia). Sądzę, że wyliczenia wynikające z przepisów reguły wydatkowej są istotnym materiałem finansowym sporządzonym przez organy opracowujące projekt ustawy budżetowej, wskazującym na obraz sytuacji finansowej państwa i jej ograniczenia (zwłaszcza w zakresie poziomu długu i deficytu publicznego). Powinny być one przedstawione w uzasadnieniach do projektu ustawy budżetowej. Jest zaś wątpliwe, czy takie globalne, w zasadzie makroekonomiczne, ustalenia mogą być uznane za prawie wiążące.

W art. 2 ustawy budżetowej ustalano łączną kwotę prognozowanych dochodów budżetu środków europejskich (62,400 mld zł) oraz kwotę planowanych wydatków tego budżetu (71,640 mld zł), a także wynik (deficyt) budżetu środków europejskich ustalony na 9,240 mld. Budżet środków europejskich jest składnikiem budżetu państwa (wynika to z przepisów art. 110 pkt 4, 5 i 6 u.f.p.). Dochody tego budżetu (pochodzące z budżetu UE) i jego wydatki (finansujące krajowe i regionalne programy operacyjne) są formami powiązań zachodzących pomiędzy budżetem RP a budżetem Unii Europejskiej. Dochody budżetu środków europejskich 
ustalone w załączniku nr 3 to ustalenia dotyczące poziomu dochodów poszczególnych krajowych i regionalnych programów operacyjnych. Planowane wydatki budżetu środków europejskich ustalone są w załączniku nr 4 w ramach części i działów budżetowych, a także (w obrębie działów) według poszczególnych programów operacyjnych.

$\mathrm{W}$ art. 3 ust. 1 ustawy budżetowej ustalono łączną kwotę planowanych przychodów budżetu państwa. Są to wpływy z tytułu szeroko rozumianych pożyczek państwowych, uzyskiwanych głównie w następstwie sprzedaży przez Ministra Finansów skarbowych papierów dłużnych (obligacji skarbowych, bonów skarbowych). Wpływy te ustalono w wysokości 336,211 mld zł. Łączna kwota planowanych rozchodów budżetu państwa (spłat zadłużenia z poprzednich okresów) wynosi zaś 272,230 mld zł. Przychody i rozchody są ujęte według odpowiednich tytułów prawnych (określa je załącznik nr 5).

W art. 3 ust 2. ustawy budżetowej ustalone jest planowane saldo przychodów i rozchodów budżetu państwa. Jest to łączna kwota wskazanych wyżej dwóch deficytów: budżetu państwa i budżetu środków europejskich. Wspomniane saldo to kwota 63,980 mld zł. (54,740 mld + 9,240 mld). Deficyt budżetu środków europejskich jest finansowany w ramach finansowania potrzeb pożyczkowych budżetu, tak jak deficyt budżetu państwa. Według art. 4 źródłem pokrycia potrzeb pożyczkowych budżetu państwa, w tym pokrycia deficytu budżetu państwa, są środki pozostające na rachunkach budżetu państwa 31 grudnia 2015 r. 6 , przychody z tytułu sprzedaży skarbowych papierów wartościowych, przychody z tytułu kredytów i pożyczek, przychody z prywatyzacji i z innych tytułów. Finansowanie wydatków ze źródeł zwrotnych stanowi istotną część ogółu wydatków budżetu państwa.

Art. 5 ustawy budżetowej ustala, że limit przyrostu zadłużenia na dzień 31 grudnia 2016 r. z tytułu zaciągniętych i spłaconych kredytów lub pożyczek oraz emisji i spłaty skarbowych papierów wartościowych nie może przekroczyć kwoty 110 mld zł. Chodzi tu o przyrost długu Skarbu

6 Występowanie środków na rachunkach budżetu państwa ma znaczenie dla zachowania płynności budżetu. Brak tych środków na rachunkach państwa byłby oznaką trudności w bieżącej wypłacalności. 
Państwa związanego z finansowaniem deficytu i spłatą długu państwowego. Przepisy art. 5 należy traktować jako udzielone rządowi upoważnienie - zawarte w ustawie budżetowej - do finansowania deficytu i spłat zadłużenia. Upoważnienie to ma określone ramy czasowe (rok budżetowy) i kwotowe. Według u.f.p. ustawa budżetowa określa limit zobowiązań z tytułu zaciągniętych kredytów i pożyczek oraz emitowanych papierów wartościowych (por. art. 82, art. 95 ust. 2 i art. 110 pkt 10 u.f.p.).

Rozwinięciem uregulowań dotyczących finansowania potrzeb pożyczkowych są ustalenia załącznika nr 5 do ustawy, które wskazują na przychody i rozchody budżetu państwa, potrzeby pożyczkowe netto budżetu państwa oraz ich finansowanie. Przychody i rozchody ujęte są jako: krajowe (przychody 204,111 mld, rozchody 159,139 mld), zagraniczne (przychody 131,878 mld, rozchody 109,656 mld) oraz przychody i rozchody z tytułu prywatyzacji. W tej ostatniej grupie saldo jest ujemne (3,212 mld zł.). Dominującą pozycją rozchodów w tej grupie załącznika jest pozycja pt. „refundacja dla FUS z tytułu przekazywania składek emerytalnych do OFE” (3,212 mld zł). W ramach rozchodów z tytułu prywatyzacji ustalone są (w załączniku) odpisy na fundusze celowe (Fundusz Reprywatyzacji, Fundusz Restrukturyzacji Przedsiębiorców, Fundusz Skarbu Państwa, Fundusz Nauki i Technologii Polskiej), a także odpis na Fundusz Rezerwy Demograficznej oraz odpisy na inne cele.

Potrzeby pożyczkowe netto (tj. zapotrzebowanie na środki zwrotne po potrąceniu kwot przeznaczanych na spłaty pożyczek i wykup obligacji skarbowych) ustalone są na poziomie 74,677 mld zł. W ramach potrzeb pożyczkowych netto finansowane są: deficyt budżetu państwa $(54,740$ mld), deficyt budżetu środków europejskich (9,240 mld), refundacja dla FUS z tytułu przekazywania składek emerytalnych do OFE (3,212 mld), kredyty i pożyczki udzielone (6,712 mld), prefinansowanie zadań realizowanych z udziałem środków z budżetu UE (0,432 mld). Finansowanie potrzeb pożyczkowych realizowane jest głównie poprzez sprzedaż skarbowych papierów wartościowych, dokonywaną w kraju i za granicą. 


\section{b) załączniki}

Zgodnie z art. 122 u.f.p. w ramach ustawy budżetowej powinny być ujęte załączniki odnoszące się do gospodarki budżetowej państwa, która nie jest objęta budżetem państwa. Zawarte w tych załącznikach plany finansowe mają odrębną (w stosunku do budżetu państwa) pozycję, strukturę i charakter. Ustalenia zawarte $\mathrm{w}$ załącznikach to regulacje uzupełniające w stosunku do ustaleń składających się na budżet państwa. Ustalenia zawarte w załącznikach pełnią jednak funkcje prawne. Są to budżety dodatkowe, które - ze względu na swą naturę i przedmiot - nie mogą być bezpośrednio włączone do budżetu państwa. Nie można „dodać” ich do budżetu państwa, muszą one funkcjonować odrębnie.

W załącznikach tych ustala się plany finansowe: agencji wykonawczych, instytucji gospodarki budżetowej, państwowych funduszy celowych, niektórych państwowych osób prawnych. Plany finansowe agencji wykonawczych ujmuje się oddzielnie dla każdej agencji z wyodrębnieniem jej przychodów (w tym dotacji z budżetu państwa), kosztów (w podziale na koszty funkcjonowania agencji i koszty realizacji zadań ustawowych) oraz wyniku finansowego agencji (art. 123 ust. 1 u.f.p.). Podobnie plany finansowe państwowych funduszy celowych ujmuje się oddzielnie dla każdego funduszu z wyodrębnieniem: stanu początkowego i końcowego środków pieniężnych, należności i zobowiązań, przychodów własnych, dotacji z budżetu państwa, kosztów na realizację zadań, w tym kosztów wynagrodzeń, zadań finansowanych ze środków funduszu (art. 123 ust. 2). Analogicznie mają być ustalone plany finansowe instytucji gospodarki budżetowej oraz objętych ustawą budżetową państwowych osób prawnych (art. 123 ust. 3 u.f.p.).

Regulacje dotyczące tych czterech typów podmiotów (agencji, funduszów celowych, instytucji gospodarki budżetowej, niektórych osób prawnych) wskazują, że wymienione plany finansowe budowane są w oparciu o metodę memoriałową (wymaganą przez ustawę o rachunkowości), a nie w oparciu o charakterystyczną dla budżetu państwa metodę kasową. Jest to jeden z powodów, dla których połączenie bezpośrednie budżetu państwa ze wspomnianymi planami finansowymi nie jest możliwe. 
Przepisy art. 122 u.f.p. wskazują dalsze załączniki, które powinna zawierać ustawa budżetowa i które tworzą system tej ustawy. Są to: a) wykaz jednostek otrzymujących dotacje podmiotowe i celowe oraz kwoty dotacji, b) wykaz programów finansowanych z udziałem środków z UE i innych środków zagranicznych wraz z limitami wydatków budżetu państwa przeznaczonych na finansowanie tych programów, c) wykaz wieloletnich limitów zobowiązań w kolejnych latach realizacji programów finansowanych z udziałem środków europejskich wraz z wykazem wieloletnich limitów wydatków realizowanych w ich ramach, d) plan wydatków budżetu państwa dotyczących niektórych projektów i programów finansowanych z udziałem środków zagranicznych. Wyżej wskazane elementy ustawy (załączniki) mają być ustalone w układzie: części, działy, rozdziały.

Dalszymi załącznikami do ustawy budżetowej (zgodnie z art. 122 ust. 1 u.f.p.) są: a) zestawienie programów wieloletnich w układzie zadaniowym, b) zestawienie zadań z zakresu administracji rządowej i innych zadań zleconych jednostkom samorządu terytorialnego odrębnymi ustawami, c) zakres i kwoty dotacji przedmiotowych i podmiotowych, d) plan przychodów i rozchodów budżetu państwa.

Powyższe przepisy u.f.p. dotyczące załączników znajdują odzwierciedlenie w treści ustawy budżetowej na 2016 r.

Zestawienie zadań jednostek samorządu terytorialnego finansowanych $\mathrm{w}$ formie dotacji celowych z budżetu państwa przewiduje art. 10 ustawy budżetowej i załącznik nr 7 do tego artykułu. Załącznik ten zawiera wykaz różnorodnych zadań z zakresu administracji rządowej i innych zadań zleconych samorządom w drodze ustaw. Zadania z zakresu administracji rządowej i dotacje na ich finansowanie ujęte w ramach budżetów wojewodów (które są częścią budżetu państwa) w podziale na zadania gmin, powiatów i województw. W 2016 r. kwoty dotacji na te zadania to: 26,193 mld zł dla gmin, 3,803 mld dla powiatów, 0,915 mld dla województw.

Podstawową pozycję wśród zadań z zakresu administracji rządowej i dotacji celowych z budżetu państwa dla gmin w 2016 r. zajmują dotacje przeznaczone na finansowanie świadczeń związanych z wychowaniem 
dzieci, zgodnie z przepisami ustawy z 11 lutego 2016 r. o pomocy państwa $\mathrm{w}$ wychowaniu dzieci ${ }^{7}$. Zadania $\mathrm{z}$ zakresu świadczenia wychowawczego są zadaniami z zakresu administracji rządowej finansowanymi w formie dotacji celowej z budżetu państwa (art. 29 ustawy o pomocy państwa w wychowaniu dzieci).

Wykaz jednostek, dla których zaplanowano dotacje podmiotowe i celowe, oraz kwoty tych dotacji na 2016 r. ustala, w świetle art. 11 ustawy budżetowej (i zgodnie z wymogami art. 122 u.f.p.), załącznik nr 8. W przepisach tych ustalono finansowanie zadań przy zastosowaniu dotacji podmiotowych i celowych. W załączniku nr 8 kwoty dotacji są ustalone w ramach części, działów, rozdziałów oraz poszczególnych podmiotów lub ich grup. Dotacje podmiotowe (ustalone ogółem na kwotę 23,265 mld zł) dotyczą finansowania działalności bieżącej takich podmiotów, jak: teatry, muzea, inne instytucje kultury, jednostki naukowe, szkoły wyższe, PKP Polskie Linie Kolejowe S.A., Agencja Restrukturyzacji i Modernizacji Rolnictwa, spółki wodne. Natomiast jednostki, dla których zaplanowano dotacje celowe na kwotę 45,612 mld zł (w ujęciu: część, dział, rozdział), to: stowarzyszenia, fundacje, szkoły wyższe, instytucje kultury, jednostki naukowe, ośrodki doradztwa rolniczego, parki narodowe, oddziały wojewódzkie Narodowego Funduszu Zdrowia, jednostki samorządu terytorialnego, inne podmioty uprawnione do uzyskania dotacji celowych.

Zakres i kwoty dotacji przedmiotowych i podmiotowych zawiera, zgodnie z art. 12 ustawy budżetowej (i stosownie do wymogów art. 122 u.f.p.), załącznik nr 9. Dotacje przedmiotowe (ok. 0,6 mld zł) to dotacje do krajowych kolejowych przewozów pasażerskich z tytułu uprawnień do ulgowych przejazdów, do niektórych zadań wykonywanych na rzecz rolnictwa, do posiłków sprzedawanych w barach mlecznych, na rzecz dofinansowania przesyłek ustawowo zwolnionych z opłat pocztowych oraz dofinansowania podręczników szkolnych. Dotacje podmiotowe (ustalone w kwocie 23,265 mld zł) to dotacje dla instytucji kultury (0,860 mld zł), szkół wyższych (ok. 15 mld), jednostek naukowych (1,5 mld), różnych jednostek sektora finansów publicznych (w tym agencji związanych

\footnotetext{
7 Dz.U. z 2016 r., poz. 195.
} 
z rolnictwem), jednostek niezaliczonych do sektora finansów publicznych (m.in. podmiotów działających w sferze infrastruktury kolejowej, górnictwa i kopalnictwa, nauki i szkolnictwa wyższego).

Według art. 13 ustawy budżetowej (i stosownie do art. 122 u.f.p.) zestawienie programów wieloletnich w układzie zadaniowym określa załącznik nr 10. Załącznik ten zawiera ustalenia dotyczące kilkudziesięciu programów. Ustala on jednostkę koordynującą lub realizującą program, nazwę programu (w tym zadania, podzadania i działania), cel programu, mierniki realizacji programu, koszty całkowite programu (ze wszystkich źródeł), nakłady do poniesienia z budżetu państwa (na trzy kolejne lata). Ustalenia tego fragmentu ustawy budżetowej nie dotyczą więc jednego roku, lecz kilku lat. Mają charakter ustaleń wieloletnich, określonych ustawą budżetową. Wprowadzone do realizacji i finansowania programy mają z reguły jako podstawę prawną odpowiednią uchwałę Rady Ministrów. Są tu m.in.: program wspierania niektórych inwestycji, programy dotyczące kultury i dziedzictwa narodowego, modernizacji technicznej Sił Zbrojnych, rolnictwa, szkół wyższych, ochrony zdrowia, infrastruktury drogowej i kolejowej. Programy są ujęte w tzw. układzie zadaniowym (z podaniem odpowiednich mierników realizacji) i wskazaniem na koszty całkowite programu (ze wszystkich źródeł finansowania) oraz nakłady z budżetu państwa w 2016, 2017 i 2018 roku. W roku 2016 nakłady budżetu państwa ustalono na 13,063 mld zł.

Art. 30, 31, 32, 33 ustalają (zgodnie z załącznikami nr 11, nr 12, $\mathrm{nr} 13$ i nr 14) plany finansowe agencji wykonawczych (10 agencji), instytucji gospodarki budżetowej (15 instytucji), państwowych funduszy celowych (29 funduszy, w tym Funduszu Ubezpieczeń Społecznych), niektórych państwowych osób prawnych (38 osób prawnych). Ustalenia te są wymagane przez ustawę o finansach publicznych (por. art. 122 i art. 123 u.f.p.).

W świetle art. 30 ustalone zostały (w tabelach od 1 do 10) plany finansowe: Polskiej Agencji Kosmicznej, Polskiej Agencji Rozwoju Przedsiębiorczości, Narodowego Centrum Badań i Rozwoju, Narodowego Centrum Nauki, Agencji Mienia Wojskowego, Agencji Restrukturyzacji i Modernizacji Rolnictwa, Agencji Rynku Rolnego, Agencji Nieruchomo- 
ści Rolnych, Centralnego Ośrodka Badania Odmian Roślin Uprawnych, Agencji Rezerw Materiałowych.

Instytucje gospodarki budżetowej, których plany finansowe są załączone do ustawy budżetowej (art. 31, załącznik nr 12, tabele od 1 do 15), to m.in.: Centrum Obsługi Kancelarii Prezydenta RP, Centralny Ośrodek Dokumentacji Geodezyjnej i Kartograficznej, Centralny Ośrodek Sportu, Centrum Zakupów dla Sądownictwa, Centralny Ośrodek Informatyki, Centrum Usług Logistycznych, Zakład Inwestycji Organizacji Traktatu Północnoatlantyckiego, Centrum Badań i Edukacji Statystycznej GUS.

Wśród 29 planów finansowych państwowych funduszy celowych (załączonych do ustawy budżetowej - art. 32, załącznik nr 13, tabele od 1 do 29) są m.in.: Fundusz Gospodarki Zasobem Geodezyjnym i Kartograficznym, Fundusz Kredytu Technologicznego, Fundusz Promocji Kultury, Fundusz Rozwoju Kultury Fizycznej, Fundusz Nauki i Technologii Polskiej, Fundusz Modernizacji Sił Zbrojnych, Fundusz Pracy, Fundusz Gwarantowanych Świadczeń Pracowniczych, Fundusz Reprywatyzacji, Fundusz Restrukturyzacji Przedsiębiorców, Fundusz Skarbu Państwa, Fundusz Wsparcia Policji, Państwowy Fundusz Rehabilitacji Osób Niepełnosprawnych, Fundusz Rozwiązywania Problemów Hazardowych, Fundusz Emerytalno-Rentowy, Fundusz Emerytur Pomostowych, Fundusz Ubezpieczeń Społecznych.

Niektóre działające w Polsce fundusze celowe nie są jednak załącznikami do ustawy budżetowej. Są to fundusze prowadzone lub obsługiwane przez Bank Gospodarstwa Krajowego. W szczególności jest to Krajowy Fundusz Drogowy, utworzony na mocy ustawy z 27 października 1994 r. o autostradach płatnych oraz o Krajowym Funduszu Drogowym ${ }^{8}$, Fundusz Kolejowy, powołany na podstawie ustawy z 16 grudnia 2005 r. o Funduszu Kolejowym ${ }^{9}$, a także inne fundusze ${ }^{10}$.

Dz.U. z 2015 r., poz. 641 ze zm.

Dz.U. z 2014 r., poz. 1201 ze zm.

Konstrukcję i znaczenie funduszy prowadzonych przez Bank Gospodarstwa Krajowego analizuje M. Cilak, Instrumenty wspierania rozwoju gospodarczego stosowane przez samorzq̨d terytorialny. Problematyka prawnofinansowa, Toruń 2013, s. 80 i n. 
Art. 33 i załącznik nr 14 (oraz tabele od 1 do 38) ustalają plany finansowe niektórych państwowych osób prawnych (38 podmiotów). Są to m.in. plany finansowe: Urzędu Dozoru Technicznego, Polskiego Instytutu Sztuki Filmowej, Polskiego Klubu Wyścigów Konnych, Polskiej Agencji Żeglugi Powietrznej, Transportowego Dozoru Technicznego, Polskiej Organizacji Turystycznej, Narodowego Funduszu Ochrony Środowiska i Gospodarki Wodnej, parków narodowych (23 parki), Polskiego Instytutu Spraw Międzynarodowych, Agencji Oceny Technologii Medycznych i Taryfikacji, Zakładu Ubezpieczeń Społecznych.

W przepisach ustawy budżetowej nie ma danych dotyczących planów finansowych dotyczących spółek Skarbu Państwa i przedsiębiorstw państwowych. Wspomniane spółki i przedsiębiorstwa nie są według przepisów ustawy o finansach publicznych (art. 9 pkt 14) zaliczane do sektora finansów publicznych. Sądzę, że informacje i ustalenia dotyczące planów finansowych tych podmiotów (w szczególności wpłaty do budżetu, dotacje z budżetu) powinny być załącznikiem do ustawy budżetowej. Przedstawienie elementów planów finansowych spółek Skarbu Państwa i przedsiębiorstw państwowych miałoby po części charakter informacyjny. Wprowadzenie tego załącznika realizowałoby funkcję kontrolną parlamentu, związaną z uchwalaniem ustawy budżetowej.

Artykuły od 35 do 38 (i będące ich rozwinięciem załączniki nr 15, 16, 17, 18 i 19) ustalają elementy budżetu środków europejskich, wykaz programów finansowanych z udziałem środków europejskich, inne ustalenia związane z wykorzystywaniem środków z budżetu Unii Europejskiej i innych środków zagranicznych. Wprowadzenie tych ustaleń wynika z postanowień art. 121 i 122 u.f.p. oraz innych przepisów.

\section{c) inne postanowienia}

Ustaleniami ustawy budżetowej są postanowienia w zakresie poręczeń i gwarancji Skarbu Państwa. Według art. 6 poręczenia i gwarancje mogą być udzielane przez Skarb Państwa do kwoty 200 mld zł. Regulacja ta wynika z art. 31 ustawy z 8 maja 1997 r. o poręczeniach i gwarancjach 
udzielanych przez Skarb Państwa oraz niektóre osoby prawne ${ }^{11}$. Limit dotyczący gwarantowanych przez Skarb Państwa ubezpieczeń eksportowych i gwarancji ubezpieczeniowych ustalono - zgodnie z art. 7 ustawy budżetowej - na 15 mld zł. Postanowienia art. 7 łączą się z przepisami ustawy z 7 lipca 1994 r. o gwarantowanych przez Skarb Państwa ubezpieczeniach eksportowych ${ }^{12}$ i są wykonaniem art. 5a tej ustawy.

Art. 8 ustawy budżetowej upoważnia Ministra Finansów do dokonywania wypłat ze środków budżetu państwa z tytułu kredytów i pożyczek udzielanych na podstawie umów międzynarodowych rządom innych państw (do kwoty 2 mld), a także do udzielania ze środków budżetu państwa pożyczek dla Banku Gospodarstwa Krajowego na zwiększenie funduszy własnych (do kwoty 2 mld), dla Bankowego Funduszu Gwarancyjnego (do kwoty $4 \mathrm{mld}$ ), dla jednostek samorządu terytorialnego (do 0,2 mld), dla Korporacji Ubezpieczeń Kredytów Eksportowych S.A. (do 0,97 mld), dla Funduszu Ubezpieczeń Społecznych (do kwoty 12 mld zł). Wspomniany przepis ustawy budżetowej (art. 8) ma odpowiednie podstawy prawne. Zgodnie z art. 115 u.f.p. z budżetu państwa, w zakresie ustalonym w ustawie budżetowej, mogą być udzielane pożyczki i kredyty wynikające $\mathrm{z}$ umów międzynarodowych oraz pożyczki wynikające z odpowiednich ustaw (tj. ustawy o Banku Gospodarstwa Krajowego, o Bankowym Funduszu Gwarancyjnym, o finansach publicznych, o gwarantowanych przez Skarb Państwa ubezpieczeniach eksportowych, o systemie ubezpieczeń społecznych).

Art. 9 ustawy budżetowej (oraz załącznik nr 6) regulują kwestie dotyczące wynagrodzeń w państwowej sferze budżetowej, w tym kwoty wynagrodzeń dla osób objętych mnożnikowymi systemami wynagrodzeń i osób nieobjętych tymi systemami, kwoty bazowe (ustalono sześć odrębnych kwot bazowych) dla określonych kategorii osób (osób zajmujących kierownicze stanowiska państwowe, członków korpusu służby cywilnej, członków Krajowej Izby Odwoławczej, żołnierzy zawodowych i funkcjonariuszy, nauczycieli, zawodowych kuratorów sądowych). Regulacje ustawy budżetowej dotyczące wynagrodzeń nawiązują do ustawy

11 Dz.U. z 2015 r., poz. 1052 ze zm.

12 Dz.U. z 2015 r., poz. 489 ze zm. 
z 23 grudnia 1999 r. o kształtowaniu wynagrodzeń w państwowej sferze budżetowej $^{13}$, ustawy z 26 stycznia 1982 r. - Karta Nauczyciela ${ }^{14}$, innych ustaw.

Art. 17 ustawy budżetowej ustala dla służby cywilnej limit mianowań urzędników (200 osób), środki na wynagrodzenia (7,61 mld) i środki na szkolenia. Jest to wypełnieniem przepisów art. 7 ustawy z 21 listopada 2008 r. o służbie cywilnej ${ }^{15}$. Art. 15 ustawy budżetowej ustala etaty dla Policji (102 370 etatów), zgodnie z ustawą z 6 kwietnia 1990 r. o Policji ${ }^{16}$, która w art. 13 stanowi, że koszty związane z funkcjonowaniem Policji są pokrywane z budżetu państwa, a etaty Policji określa coroczna ustawa budżetowa.

Artykuły od 20 do 26 ustawy budżetowej regulują kwestie wymagane przez przepisy z zakresu finansów ubezpieczeń społecznych, m.in. wysokość odpisu (kwoty), o której mowa w art. 76 ust. 1 pkt 1 ustawy z 13 października $1998 \mathrm{r}$. o systemie ubezpieczeń społecznych ${ }^{17} \mathrm{i} \mathrm{w}$ art. 32 ust. 2 ustawy z 19 grudnia 2008 r. o emeryturach pomostowych ${ }^{18}$, wysokość należności dla ZUS z tytułu poboru składek na rzecz otwartych funduszy emerytalnych, kwotę wydatków na prewencję rentową i na prewencję wypadkową. Art. 26 określa prognozowane przeciętne miesięczne wynagrodzenie brutto w gospodarce narodowej na rok 2016 (obowiązek wskazania w ustawie budżetowej tego wynagrodzenia przewiduje art. 19 ust. 1 ustawy o systemie ubezpieczeń społecznych).

Art. 28 ustawy budżetowej ustala obowiązkową składkę na Fundusz Pracy w wysokości 2,45\% podstawy wymiaru. Ustalenie tej składki w ustawie budżetowej jest wymagane przez art. 104 ust. 2 ustawy z 20 kwietnia 2004 r. o promocji zatrudnienia i instytucjach rynku pracy ${ }^{19}$. Z kolei art. 29 ustala obowiązkową składkę na Fundusz Gwarantowanych Świadczeń Pracowniczych w wysokości 0,10\% podstawy wymiaru skład-
Dz.U. z 2015 r., poz. 2030 ze zm.
Dz.U. z 2014 r., poz. 191 ze zm.
Dz.U. z 2014 r., poz. 1111 ze zm.
Dz.U. z 2015 r., poz. 355 ze zm.
Dz.U. z 2015 r. poz. 121 ze zm.
Dz.U. z 2015 r., poz. 965 ze zm.
Dz.U. z 2015 r., poz. 149 ze zm. 
ki na ubezpieczenia emerytalne i rentowe, czego wymaga art. 29 ust. 2 ustawy z 13 lipca 2006 r. o ochronie roszczeń pracowniczych w razie niewypłacalności pracodawcy ${ }^{20}$. Ustawa budżetowa określa więc, w art. 28 i 29, wysokość procentową niektórych danin publicznych na dany rok budżetowy.

Formą powiazań budżetu państwa z samorządami określoną w ustawie budżetowej są wpłaty wyrównawcze jednostek samorządu terytorialnego (związane z mechanizmem wyrównań w zakresie dochodów podatkowych pomiędzy samorządami tego samego szczebla). Art. 27 ustawy budżetowej ustala kwoty wpłat gmin, powiatów i województw do budżetu państwa, o których stanowi art. 7 ust. 2 ustawy z 13 listopada 2003 r. o dochodach jednostek samorządu terytorialnego $^{21}$. Wpłaty te są podstawą tworzenia subwencji równoważących i regionalnych. Kwoty wpłat w 2016 r. wynoszą: dla gmin - 0,531 mld zł, dla powiatów - 1,123 mld, dla województw - 0,317 mld.

Przepisy artykułów 18 i 19 ustawy budżetowej określają wskaźniki cen towarów i usług, na których stosowanie (używanie do opracowywania określonych planów i wyliczeń finansowych) powołują się różne ustawy. Art. 18 określa, że w 2016 r. prognozowany średnioroczny wskaźnik cen towarów i usług konsumpcyjnych wynosi 101,7\%. Wskaźnik ten jest powszechnie wykorzystywany w planowaniu wydatków, dochodów oraz indeksowaniu niektórych opłat. Stosujące wskaźnik podmioty powinny mieć możliwość powołania się na oficjalne źródło, jakim jest przepis zawarty w ustawie budżetowej (por. - rozdział XV uzasadnienia do projektu ustawy budżetowej na 2016 r.). Art. 19 ustala prognozowany średnioroczny wskaźnik cen towarów i usług konsumpcyjnych dla gospodarstw domowych emerytów i rencistów (ustalony został na poziomie 102\%).

20 Dz.U. z 2014 r., poz. 272 ze zm.

21 Dz.U. z 2016 r., poz. 198. 


\section{Niektóre uwagi pod adresem ustawy budżetowej na 2016 rok}

Jednym z problemów prawnych ustawy budżetowej jest problem jej szczegółowości. Według art. 116 u.f.p. dochody budżetu państwa (podatkowe i niepodatkowe) ujmuje się w załączniku do ustawy budżetowej według: 1) źródeł dochodów oraz 2) części i działów klasyfikacji budżetowej. Natomiast wydatki budżetu państwa ujmuje się w załączniku do ustawy budżetowej w podziale na części, działy i rozdziały klasyfikacji budżetowej.

Pojawia się problem szczegółowości ustaleń budżetu po stronie wydatków, tj. brak ustawowego obowiązku do ustalenia podziału wydatków według paragrafów budżetowych. Paragrafów tych jest kilkaset. Są one elementami rozdziałów budżetowych. Pojawia się problem wykonywania ustaleń budżetu państwa w ramach paragrafów i odpowiedzialności prawnej za naruszenia dotyczące wydatków ustalonych w paragrafach, skoro ustaleń tych - ustawą budżetową określonych - nie ma.

Ustalenia dotyczące podziału wydatków na paragrafy budżetowe występują w ramach planów finansowych przygotowanych przez jednostki budżetowe (por. art. 143 i 146 u.f.p.), ale nie w ramach ustaleń samej ustawy budżetowej. Czy sporządzony przez jednostkę budżetową plan finansowy, który ma być zgodny z ustawą budżetową (i który zapewne jest zatwierdzony przez dysponenta części budżetowej), jest aktem prawym? Czy jest aktem powszechnie czy wewnętrznie obowiązującym? Czy w związku z niejasną pozycją prawną tego planu finansowego jego naruszenie (w zakresie paragrafów) jest czynem, który powinien podlegać karze? W świetle art. 11 ustawy z 2004 r. o odpowiedzialności za naruszenie dyscypliny finansów publicznych naruszeniem jest dokonanie wydatku bez upoważnienia określonego ustawą budżetową, uchwałą budżetową lub planem finansowym. Sankcje za naruszenia postanowień zawartych w ustawie budżetowej lub uchwale budżetowej w zasadzie nie budzą wątpliwości. Inaczej jest, gdy chodzi o naruszenie postanowień planu finansowego. 
Sądzę, że nie byłoby takich wątpliwości, gdyby podział wydatków na paragrafy był dokonany w ustawie budżetowej (co wydaje się z techniczno-organizacyjnych względów bardzo trudne lub niemożliwe) lub gdyby podział wydatków na paragrafy był dokonywany przez ministra (lub innego dysponenta części budżetowej) w drodze aktu normatywnego (w drodze rozporządzenia lub zarządzenia). Gdyby ustalenia szczegółowe dotyczące podziału wydatków na paragrafy były przedmiotem rozporządzenia wydawanego na podstawie ustawy o finansach publicznych w nawiązaniu do ustawy budżetowej na dany rok, to ich naruszenie stałoby się naruszeniem postanowień aktu normatywnego powszechnie obowiązującego. Problematyka ta nawiązuje do stosowanych w poprzednich latach tzw. układów wykonawczych budżetu.

Zgodnie z art. 128 ustawy z 30 czerwca 2005 o finansach publicznych $^{22} \mathrm{w}$ terminie 21 dni od dnia ogłoszenia ustawy budżetowej dysponenci części budżetowych przedstawiają Ministrowi Finansów szczegółowy plan dochodów i wydatków danej części budżetowej, zwany „układem wykonawczym”. Układ ten opracowuje się w podziale na działy, rozdziały i paragrafy klasyfikacji dochodów i wydatków. Układ wykonawczy opracowany przez dysponenta części budżetowej jest aktem ustalającym podział wydatków na paragrafy. Sądzę, że z punktu widzenia pełnionej przez układ wykonawczy funkcji można przypisać mu znaczenie aktu prawnego o cechach normatywnych (wiążące rozłożenie wydatków na paragrafy). Skoro podział na części, działy i rozdziały jest ustalony w ustawie, to dalszy podział wydatków - na paragrafy - powinien być dziełem mającym cechy normatywności. Analogiczna regulacja dotycząca układów wykonawczych zawarta jest w art. 89 ustawy z 26 listopada 1998 r. o finansach publicznych ${ }^{23}$.

Istotnym aspektem wpływającym na kształt i układ ustawy budżetowej jest odmienne $\mathrm{w}$ stosunku do budżetu ujmowanie planów finansowych zawartych w załącznikach, w tym planów finansowych agencji wykonawczych, funduszy celowych, instytucji gospodarki budżetowej i innych państwowych osób prawnych. Budżet państwa ujmowany jest zgod-

22 Dz.U. Nr 249, poz. 2104.

23 Dz.U. Nr 155, poz. 1014. 
nie z metodą kasową (według płatności dokonywanym w danym roku budżetowym). Art. 40 ust. 2 pkt 1 u.f.p. stanowi, że plany kont dla budżetu państwa powinny uwzględniać, że dochody i wydatki ujmuje się w terminie ich zapłaty, niezależnie od rocznego budżetu, którego dotyczą. Natomiast podmioty i instytucje wchodzące w skład ustawy budżetowej, których plany finansowe zawarte są w załącznikach do ustawy budżetowej ujmowane są w ujęciu memoriałowym (tj. w ujęciu należności, zobowiązań, przychodów, kosztów, wyniku finansowego), zgodnie z wymogami ustawy o rachunkowości. Sprawia to jednak, że finansowe ustalenia ustawy budżetowej nie są jednorodne. Wyrażają inne kategorie ekonomiczne, finansowe i prawne. Brak jednorodności ustaleń ustawy budżetowej (budżetu i załączników) sprawia, że połączenie wszystkich zawartych w ustawie budżetowej planów finansowych w jeden, jednolity, scalony dokument jest niemożliwe. Dodać też trzeba, że w systemie publicznym może być stosowana metoda zarówno kasowa, jak i memoriałowa ${ }^{24}$.

Istotną cechą polskiej ustawy budżetowej jest to, że zawiera ona nie tylko postanowienia dotyczące roku budżetowego. Część jej ustaleń (programy wieloletnie, programy finansowane z udziałem środków europejskich) ma wymiar wieloletni. Są to ustalenia dotyczące zadań, wydatków, limitów na dany rok i na kilka lat następnych. I chodzi tu o ustalenia ustawy budżetowej (w tym załączników do ustawy), a nie postanowienia uchwały Rady Ministrów w sprawie wieloletniego (czteroletniego) planu finansowego państwa. Coroczna uchwała w sprawie wieloletniego planu finansowego państwa nie ma takiej rangi prawnej jak ustawa budżetowa.

\section{Podsumowanie}

Ustawa budżetowa na 2016 r. ustala dochody, wydatki, przychody, rozchody, koszty, wynagrodzenia, stawki należności, odpisy na fundusze. Ustalenia te odnoszą się do gospodarki finansowej administracji rządowej, a także innych członów gospodarki państwa (ubezpieczeń społecznych,

24 Por. K. Winiarska, M. Kaczurak-Kozak, Rachunkowość budżetowa, Warszawa 2011, s. $31 \mathrm{i} \mathrm{n.}$ 
agencji państwowych, funduszów celowych, różnych państwowych osób prawnych). Ustawa ta zawiera postanowienia wynikające z wielu odrębnych ustaw. Jest rozwinięciem lub wykonaniem uregulowań zakotwiczonych w całym porządku prawnym.

Dla poszczególnych wyodrębnionych dziedzin gospodarki finansowej państwa należy przyjąć odpowiednie sformułowania prawne, legislacyjne. Głównym elementem ustawy budżetowej jest budżet państwa (budżet ogólny), a innymi składnikami tej ustawy są budżety (plany finansowe) uzupełniające. Dla tych różnych budżetów i planów finansowych (ujętych w ustawie budżetowej) należy stosować odpowiednie, adekwatne do natury tych budżetów i planów nazwy ich operacji finansowych: dochody i wydatki (dla budżetu państwa), przychody i koszty (dla budżetów uzupełniających), przychody i rozchody (dla planu finansowania potrzeb pożyczkowych). Zależy to od natury danej dziedziny gospodarki finansowej państwa, a także od kasowej lub memoriałowej metody ujmowania zdarzeń finansowych. Przykłady dotyczące konstrukcji i treści ustaw budżetowych (finansowych) można czerpać z systemu prawnego II Rzeczypospolitej i systemów innych państw.

Przykładowo, polska ustawa skarbowa z 29 marca 1938 r. na okres od 1 kwietnia 1938 do 31 marca $1939^{25}$ składała się z czterech grup budżetowych, odzwierciedlających odpowiednie człony finansów państwa (A - Administracja, B - Przedsiębiorstwa i Zakłady, C - Monopole i D Fundusze). Grupa A posługiwała się kategoriami: dochody i wydatki (dochody i wydatki Skarbu), inne grupy budżetowe były powiązane z grupą A (dopłatami ze Skarbu lub wpłatami do Skarbu) i stosowały inne pojęcia dotyczące ich działalności finansowej, a mianowicie: rozchody i wpływy. Inny przykład to ustawa francuska. Składnikami ustawy finansowej we Francji są budżety załączone do tej ustawy: A, B, C, D i E. W ustawie francuskiej występuje podział materii budżetowej na kilka elementów, wśród których występuje budżet ogólny, a także budżety załącznikowe, rachunki specjalne, rachunki finansowe ${ }^{26}$.

25 Dz.U. Nr 20, poz. 161.

26 Na temat ustawy budżetowej w Polsce, Niemczech i Francji, por. A. Borodo, Wspótczesne problemy prawne budżetu państwowego, Toruń 2014, s. 80 i n. 
Aktualny układ i treść ustawy budżetowej w Polsce wymaga zmian. Układ ten nie zawiera ustaleń dotyczących niektórych ważnych państwowych funduszy celowych (zwłaszcza Krajowego Funduszu Drogowego) oraz informacji lub ustaleń dotyczących planów finansowych spółek Skarbu Państwa.

Niektóre artykuły ustawy budżetowej powinny być rozwinięte, wypełnione odpowiednimi regulacjami. Nie powinny jedynie odsyłać do załączników. Jest wskazane, aby niektóre elementy uregulowań zawartych w załącznikach przesunąć do tekstu głównego.

Uzasadnione jest też, aby - stosownie do wymogów ustawy o finansach publicznych - wprowadzić do ustawy budżetowej wyodrębnione legislacyjnie trzy elementy: I. budżet państwa (i związane z nim załączniki), II. załączniki (budżety uzupełniające) i III. inne postanowienia.

\section{Bibliografia:}

Borodo A., Współczesne problemy prawne budżetu państwowego, Wydawnictwo Naukowe Uniwersytetu Mikołaja Kopernika, Toruń 2014.

Borodo A., Ustawa budżetowa na 2015 rok oraz propozycje zmian układu ustawy budżetowej w Polsce, „Prawo Budżetowe Państwa i Samorządu” 2015, nr 1(3), str. 9-26.

Cilak M., Instrumenty wspierania rozwoju gospodarczego stosowane przez samorzq̨d terytorialny. Problematyka prawnofinansowa, TNOiK, Toruń 2013.

Winiarska K., Kaczurak-Kozak M., Rachunkowość budżetowa, Oficyna a Wolters Kluwer business, Warszawa 2011. 